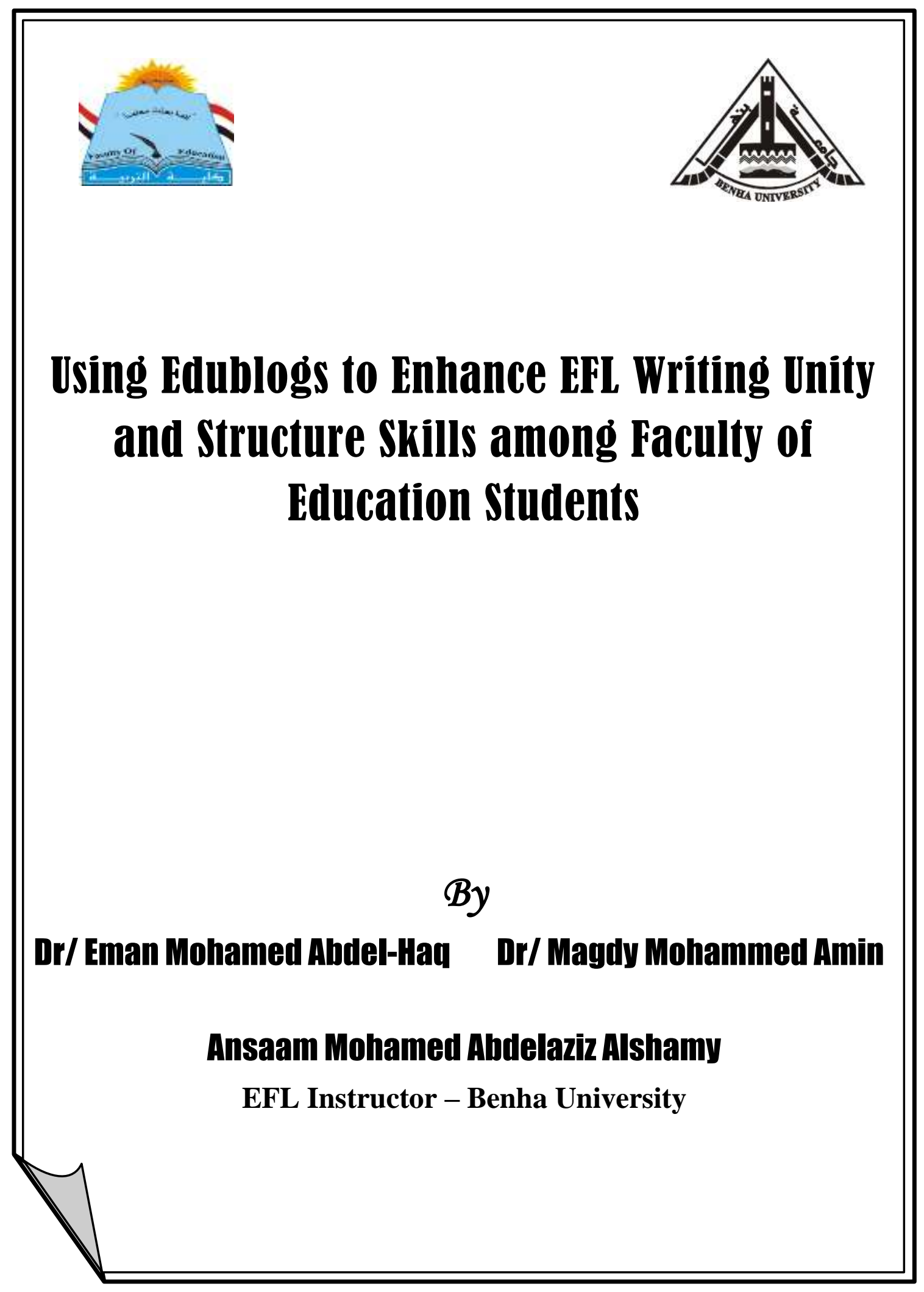




\section{Using Fdublogss to Enhance EFL Writing Unity and Structure Skills among Faculty of Education Students}

By

Dr/ Eman Mohamed Ahdel-Hau

Dr/ Magdy Mohammed Amin

Ansaam Mohamed Ahdelaziz Alshamy

EFL Instructor - Benha University

\section{Abstract}

The aim of the present study was to enhance EFL writing unity and structure skills among third year Student- Faculty of Education- Benha University through using the edublogs. The participants of the study consisted of third year English section students enrolled in Faculty of Education, Benha University ( $\mathrm{N}=31)$. The study followed the one-group pre-posttest design. In addition, it used quantitative method for collecting and analyzing the data. The instruments of the present study were: an EFL writing skills checklist, an EFL writing test and a rubric to score it. Using the edublogs was applied to the participants during the first semester of the academic year 2017/2018. Results of the quantitative analysis revealed that the participants' EFL writing unity and structure skills were improved significantly as a result of using edublogs. Therefore, it can be concluded that that using edublogs is effective in improving the EFL writing unity and structure skills among prospective teachers of English.

Keywords: EFL writing skills, edublogs, Unity, Structure. 


\section{هلخص البحث باللغة العربية}

يهدف هذا البحث الى تعزيز مهارتي التركيب والتماسك في الكتابة باللغة الانجليزية كلغة أجنبية لاى طلاب الفرقة الثالثة شعبة اللغة الاتجليزية بكلية التربية جامعة بنها وذلك باستخدام

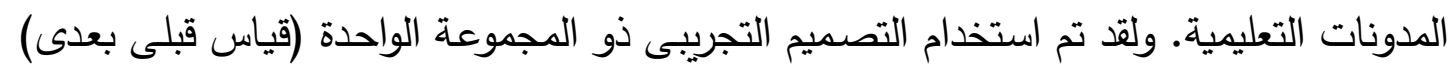

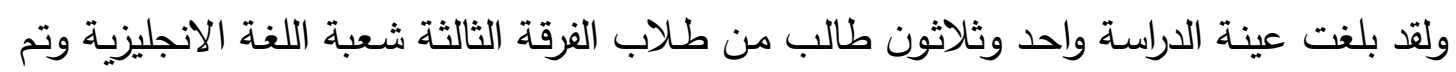

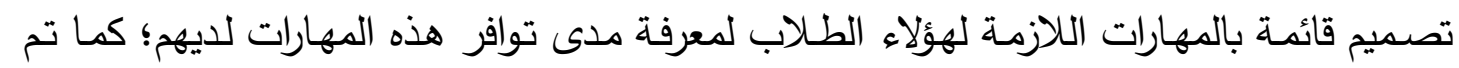
تحكيمها بواسطة عدد من المحكمين الخبراء فى مجال المناهج وطرق تدريس اللغة الإنجليزيـة.

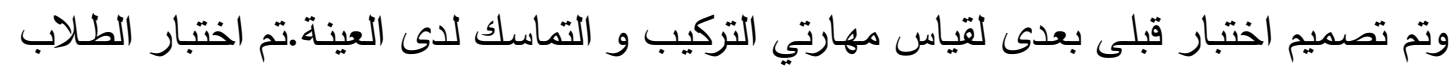

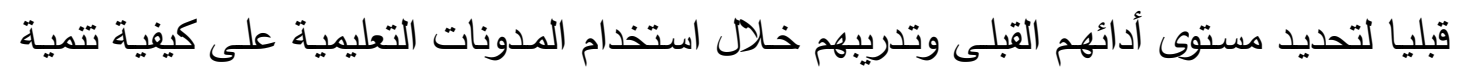

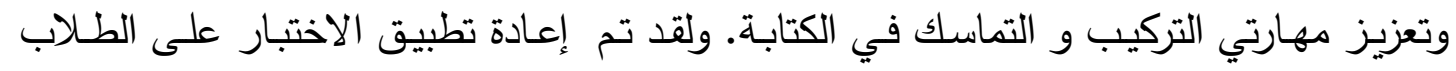

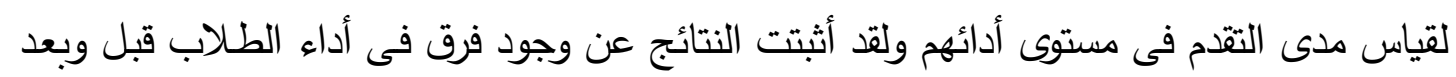

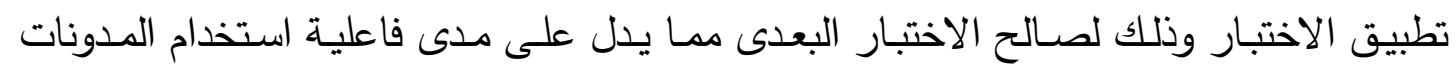
التعليمية لتعزيز وتتمية مهارتي التركيب و التماسك في الكتابة باللغة الانجليزية. كلمات مفتاحية: التماسك، التركيب، مهارات الكتابة، المدونات التعليمي. 


\section{Introduction}

Writing is a critical skill for students in school, college, and lifelong. Writing is also important for the instruction of foreign and second language learners because writing well is a main skill for academic success. Writing is an effective tool to develop the academic language proficiency as writing expression allows learners to raise their awareness of knowledge gaps and elaborate mental representations of knowledge that can be more easily retrieved. Also writing allows teachers to understand the students' state of knowledge and thinking process and thus adjust instruction as necessary (Aljumah, 2012).

Elashri (2013) stated that writing is one of the most important skills in English language. It permits writers to investigate points of view and thoughts, and make them noticeable and concrete.Writing supports thinking and learning, inspires correspondence and makes thought accessible for reflection. At the point when believed is composed down, thoughts can be inspected, reexamined, added to, revamped, and changed.

Ryan (2014:130) defined writing as a complex and learned activity in that it requires us to shape our thoughts into words and texts that are appropriate for the purpose, audience and medium of a variety of communicative forms. Writers must constantly make decisions about how to represent their subject matter and themselves through language. In this way, writing can be conceptualized as a performance whereby writers shape and represent their identities as they mediate social structures and personal considerations.

The value of writing is affirmed by research. That demonstrates its esteem for academic and other related purposes. Writing is a profitable tool for sharing one's ideas to others. It serves both advance feeling of possession and expressing human internal emotions. Writing is the 
commonest method for surveying students' performance in English particularly in the Arab nations (Salem, 2013).

Writing is a vital skill that must be learned appropriately by university learners, particularly EFL student teachers. In order to express their thoughts productively academically, they must be prepared well on the most proficient method to write important pieces (e.g. papers, scholarly reports, critical reviews, etc.). Additionally, writing is an important skill that prospective English language teachers need to improve during their pre-service education (training) programmes (Abdallah, 2015).

Toci (2014) considered writing the main factor for the academic language success. Students, from their early age, learn the foreign language. They acquire it first through letters and simple words then they go on learning with longer sentences, paragraphs and reach to write a whole paper. However writing in a foreign and universal language like English is a basic skill these days. It is critical as it can help learners to communicate, learn and express inventiveness. Additionally, helping students possessing skills remains an important instructive objective since writing assumes a key part in the learner's theoretical and mental improvement (Isleem, 2012).

According to Tangpermpoon (2008), writing is considered as the most challenging skill for language learners. They need a specific amount of second language knowledge about the appropriate language use or suitable vocabulary in order to be able to communicate with their readers. Sahin and Genc (2015:210) defined writing as "the only productive learned skill that proves to be highly challenging for native speakers and this challenge becomes more daunting when the issue is writing in a foreign language".

The value of writing is affirmed by research. That demonstrates its esteem for academic and other related purposes. Writing is a profitable 
tool for sharing one's ideas to others. It serves both advance feeling of possession and expressing human internal emotions. Writing is the commonest method for surveying students' performance in English particularly in the Arab nations (Salem, 2013).

Writing is a vital skill that must be learned appropriately by university learners, particularly EFL student teachers. In order to express their thoughts productively academically, they must be prepared well on the most proficient method to write important pieces (e.g. papers, scholarly reports, critical reviews, etc.). Additionally, writing is an important skill that prospective English language teachers need to improve during their pre-service education (training) programmes (Abdallah, 2015).

It is very important to understand that writing as any other language learning skills (reading, speaking, and listening), is affected by the progressions interceded on the pedagogy. Twenty years ago, the process and product approaches had commanded a significant part of teaching writing that includes in the ESL/EFL classrooms (Hussin, et al., 2015).

The product approach concerns the last written content, for instance the text, length or spelling of a composed story. The process approach looks at how that content came about. All the more particularly, studies of the writing process may examine components such as the speed of translation and updates made to the content (Torkildsen, Morken, Helland \& Helland, 2015).

The product approach is a traditional approach to teaching writing in which the teacher is the model who is being typically mimicked by his students in order to produce a similar product (Elashri, 2013). The genre as a product implies that genre writing is a sort of text or writing work itself. Genre writing as a product or kind of writing demonstrates its typical elements as appeared by its organization, rhetoric structure, as well as linguistics features (Dirgeyasa, 2014). 
This approach was concerned essentially with the completed product in coordinating learners toward pre-determined targets. With this approach, teachers concentrate on the last state of a piece of composing and measure it against criteria of vocabulary use, linguistic use and mechanics of writing. Ordinarily, learners in the product approach writing classes would learn texts. Trying different drills leads to draw the student-writers' attention for the pertinent elements of a content. A definitive objective is for students to deliver a comparable content to the one they have experienced. Such an approach neglects to think about the non-local understudy's individual needs (Isleem, 2012).

Writing, unlike speaking, gives a way not only to produce thoughts before introducing them to an audience, but also to examine the creating thoughts and language. This seeing again gives a chance to get criticism from ourselves as well as other people and, learning can make improvements and changes (Raimes 2002, p.309).

Raimes and Miller-Cochran (2013) identify the process of writing as focusing on content, fluency, personal voice and revision. Writing process must go through a sequence of several overlapping and recurring activities. Carolan and Kyppö (2015) asserted that the writing process should include teaching the learners how to write in different genres and how to form their academic texts according to writing conventions.

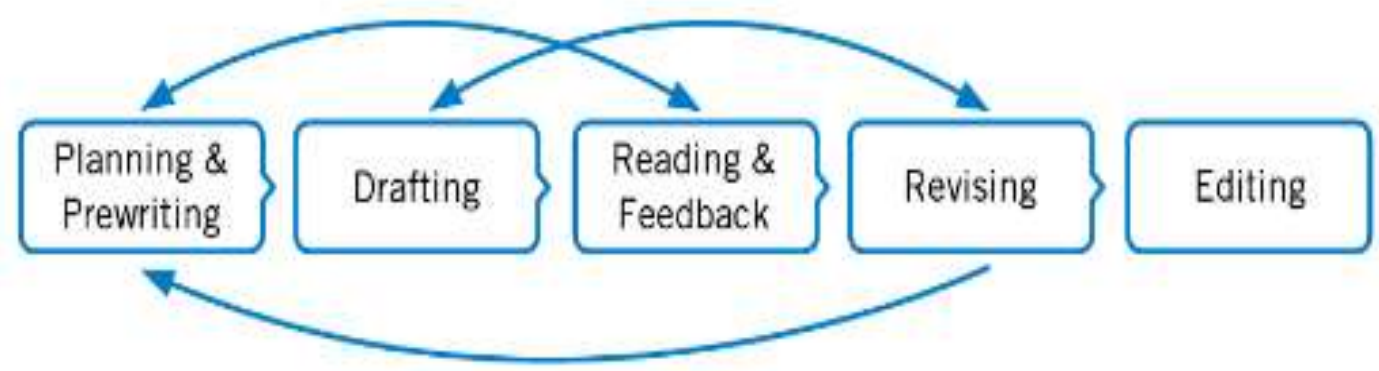

Figure1. A sequence of several overlapping and recurring activities, adapted from Raimes and Miller-Cochran (2013:11) 
The writing process should include some essential phases. Planning is the first stage of the writing process in which the writer thinks about the topic that will be expressed. Not only the topic but also the elements and ideas can support his writing. After planning, it is time to write a draft that have to include the topic with its supporting sentences. Reading and giving feedback is the third stage after drafting. In this stage, the writer should read his draft and decide if there will be any modification or errors in the written text. Then the revision stage takes place in which the writer plays a role of the reviewer. He should criticize his writing and conclude what points need modification. Editing includes checking the grammatical mistakes, vocabulary and punctuation.

Process writing as a classroom movement consolidates the four essential writing stages - planning, drafting (writing), revising (redrafting) and editing. The three different stages remotely forced on students by the teacher, to be specific, responding (sharing), evaluating and post-writing. Process writing in the classroom is organized as it requires the methodical instructing of process skills, and in this way it may not, at any rate at first, offer approach to a free variety of writing stages (Seow, 2002).

In writing classes, students must know where to start, what to do at each stage and what is expected of them when writing texts (Diliduzgun, 2013). Writing is the process of putting the information structured in the mind on paper. For this, it is necessary for students to understand what they hear and read well and structure it in their minds (Akdal and Sahin, 2014).

Karadeniz (2017) stated that structure skillincludes comprising words, prefixes and suffixes and sentences. These elements come together and complete each other, forming meaningful phrases. Therefore, revealing the connection between these prefixes and suffixes, words and phrases is important in order to make a sound interpretation of

\section{9}


the text. Revealing the connection is what we call cohesion. Structure in a written text is to use other elements to explain or interpret an element within the text and to make explanations based on these elements.

The rules for sentence structure such as the subject, object and verb agreement were verbally taught to the class which contributed to the better results in the area of general English grammar and the text structure of the students (Graham \& Harris, 2005).

A study conducted by Sadik (2009) discovered that problems in writing were associated with limited knowledge of writing strategies, problem with grammatical structure, and low interest in writing. She also discovered that the students did not realize that writing is time consuming and tedious.

In addition to structure skill, written texts must a unity. A description of the fit of a text to its context, as well as descriptions of what composition teachers call writing quality, must specify a variety of unity conditions, many of them outside the text itself (Witte\& Faigley, 2003).

Unity skill is a very important characteristic of good writing. Text unity means that one essay is about only one main topic. That is, all the sentences -- the topic, supporting sentences, the detail sentences, and (sometimes) the concluding sentence -- are all telling the reader about one main topic. If written text contains a sentence or some sentences that are not related to the main topic, then this piece of writing lacks unity (Ali, 2016).

Breyer (2009) stated that the advent of computers has brought about significant changes to the study of language. In fact, the concept of language, the way of studying it and what exactly it is have changed dramatically since computer technologies have become widely available to the research community.

Internet can be used to support the writing process. Students can improve their own writings abilities and skills in different genres as the 
internet can motivate learners especially the ones who are familiar with using technology. In case of using the internet to serve the language learning process, the teacher should know how to play the role of the facilitator very effectively. Furthermore, teachers who have never utilized blogs or online networking for the advancement of process writing may feel lost about what phases to take to make the activities responsive and incentive. Luckily, these teachers can counsel generally accessible and easy to use online assets to make the innovation available. (Boas, 2011).

A weblog is an innovation of the internet as it provides a realworld activity for students. By using a weblog, students will have new and interesting ways to write as they can enjoy posting, reading their classmates' posts and making comments on those posts and thus it can improve their writing skills (Aljumah, 2012).

A weblog or blog can be described as an online journal with one or many contributors. Besides straight text and hyperlinks, many blogs incorporate other forms of media, such as images and videos. A blog has many characteristics which are date and time the post was published, category the post is labelled with (can be one or more), main title of the post, main content of the post, links back from other sites, comments added by readers, the URL of the full, individual article and footer usually at the bottom of the post, often showing post date/time, author, category, and status such as number of reads, comments or trackbacks (Duffy \& Bruns, 2006).

Weblog is a type of web application that displays serial entries with date and time stamps. Blogs also possess some features that might help facilitate learning. First, blogs are easy to use. For example, after finishing editing a new post or writing a comment in a blog platform, the post and comment can be instantly published in the cyberspace with a click of the submit button. In addition, blogs can automatically archive the posts in the reverse chronological order with the dates stamped, and it is easy to find 
past works. As blog technology is easy to use for both instructors and learners, the application of blogs in the educational field is becoming increasingly popular. Second, blogs have much to offer to literacy. Third, blogs facilitate interaction and collaboration ( $\mathrm{Wu} \& \mathrm{Wu}, 2011$ ).

A huge number of instructors and students have officially joined weblogs into their classrooms and into their practice. Blogs, as they are known, are effortlessly made, effectively updateable web destinations that permit author (or authors) to distribute in a split to the internet from any internet connection. They can likewise be intuitive, enabling instructors and students to start discussions or add to the data distributed there. Weblogs are the most generally embraced tool of the Read/Write Web up until now (Richardson, 2010).

There are many different types of blogs, from personal to educational. A personal blog is one where the blogger uses it as an online diary, posting views on anything that they consider interesting. A career blog is one which is used to dictate a professional journey, demonstrate expertise, or network out to other professionals. A paid blog is one where a person is employed to blog for a living; this can be done to promote the company and log onto other blogs to tell others of the company. Political blogs are among the most common forms of blogs. Most political blogs are news driven, and most political bloggers will link to articles from news web sites so that they can add their own views on the subject. An educational blog is a sub form of weblogs. For many years in the past and possibly for some in the future, it has been hard for bloggers to agree on a term that best describes weblog; they are continually re-defining and debating the correct term to illustrate this genius invention. However, the typical definition of weblog which is commonly used is that a weblog is a live journal or application which can be updated immediately without any problems. Edublogs can range 
from all sorts of things such as, a diary of personal events or thoughts; a list of fascinating websites; a list of exciting computer games and soon. The list allows individuals to communicate about certain topics of interest (Curran\& Marshall, 2011).

According to Ray (2006), blogs in education or EduBlogs can be used to communicate, as instructional resources, as collaborative tools, and showcases for student projects. As an electronic bulletin board, an EduBlog provides a fast, efficient means of communication. It can be used to post class announcements for parents or providing schedule reminders for students. EduBlogs can be used as instructional resources, in which teachers can post tips, explanations, or samples to help students learn. Instructors can post hyperlinks to websites that provide assignment-related homework helpers and resources. EduBlogs can also be used as collaborative tools for student projects.

It's so easy to create and update a weblog, only basic access to the internet, and a minimum of technical knowledge is required. Computer and internet connections should be available all the time in order to make weblogs easy to create and maintain. Dewi (2013) indicated some free, simple and appropriate servers to set up and appropriate to use blogs. Some of these are even specially designed for educational purposes. Some free weblog that teachers might use for the class are: Wordpress.com, Blogspot.com, Blogger.com and Livejournal.com.

First, the way toward starting a blog was genuinely basic. To start with, the teacher enlisted as a user at a blogging site. Registration required only a minimum of personal data. The website gave assistance as much of the time made inquiries and had a natural interface, consequently the site was obvious.

Second, the instructor used the "create new blog" feature to name and describe a weblog file. This file could have been facilitated on the 
educator's decision of PC (Personal Computer) server. Generally, the teacher used Blogger as the HTML (Hypertext Markup Language) editorial manager to make the blog document and blogspot's PC to have the file and serve it as a website page. These websites were cross-connected to move from editing to viewing modes easily (Johnston, 2002).

It takes only about ten minutes to create a personal blog:

1- Create an account. "Google account": filling in all the basic information such as user name, password, and email, etc.
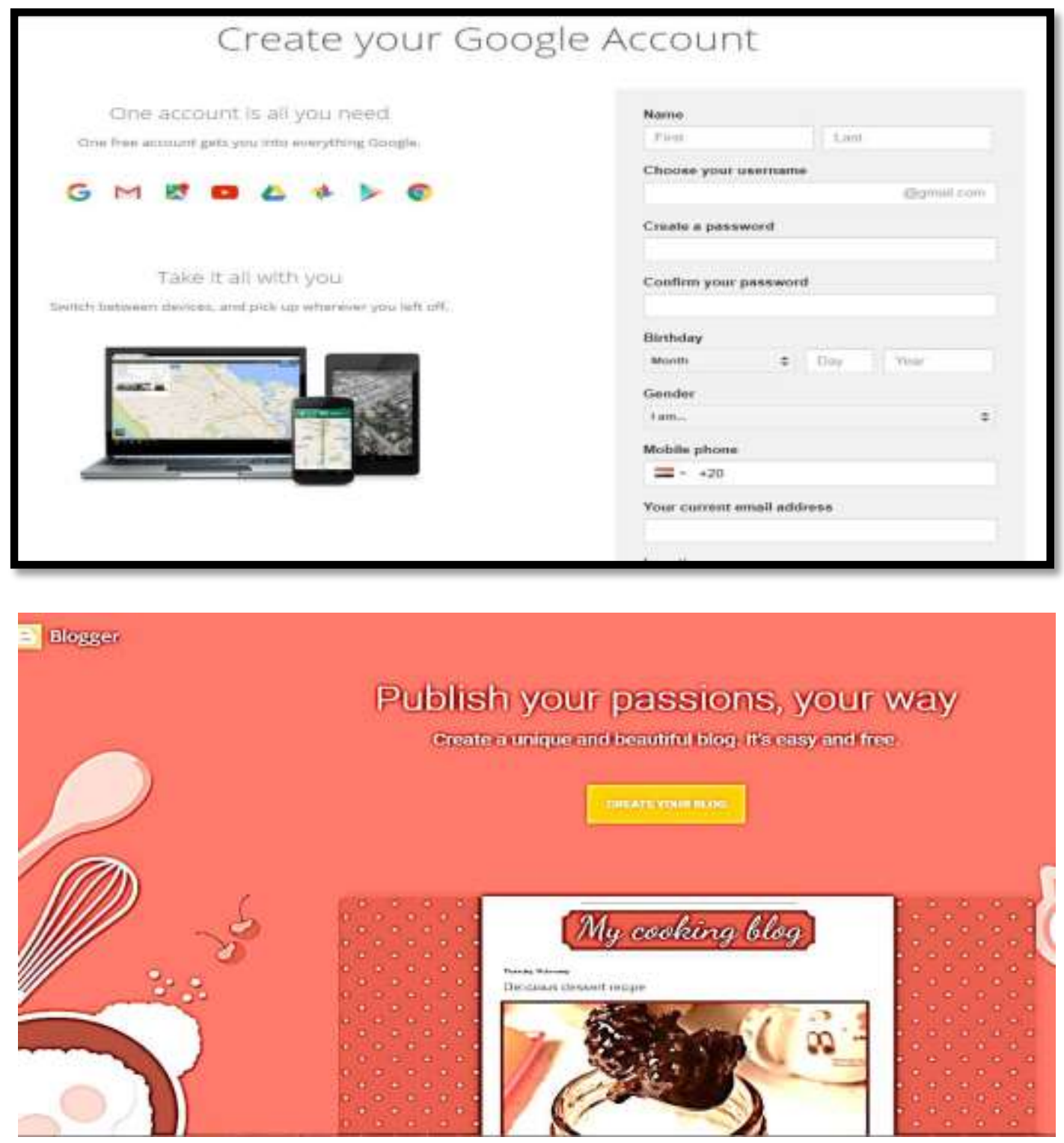
2- Naming the weblog: giving the weblog a title and decide its Universal Resource Locator (URL) address. If the weblog is being hosted at Blogger, then it is necessary to choose a unique name before blogspot.com. For example, if the blog named 'narrativewriting'; therefore, the complete URL address of that blog is http://narrativewriting.blogspot.com.

3- Choosing a template: Picking up the favorite template

\section{Blogs List , Create a new blog}

Address

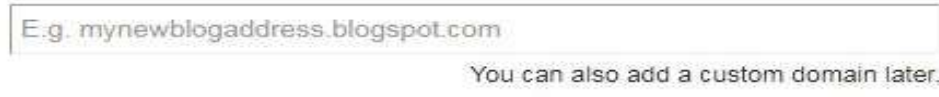

Theme

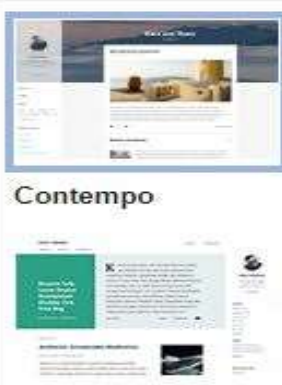

Notable

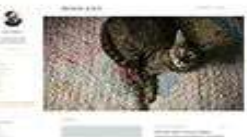

Soho

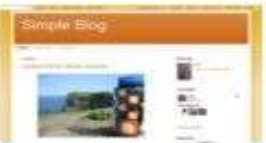

Simple

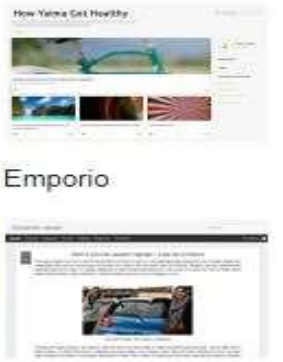

Dynamic Views

According to Abu Bakar, Latif and Ya'acob; 2010, Noytim 2010; Aljumah, 2012; weblogs have effective values in English language education as they provide opportunities for real interaction in an authentic learning environment. Thus, weblogs raise an awareness of having an authorship and a readership. They support and improve students' writing skills and abilities, provide an exciting and motivating learning environment in reading and writing for learners and promote learner autonomy .Thus, through blogging, students are able to express and share 
thoughts, ideas and information with the wider public. As an online journal, weblog allows the learners to participate actively in their own learning, determine their learning goals, and share their knowledge or in order to develop their own understanding of the target learning activities.

Duffy and Bruns (2006) described a weblog as an online journal with one or many authors. It can include not only straight text and hyperlinks but also other forms of media, such as images and video. A blog is usually made up of the following components:

- Post Date - date and time the post was published

- Category - category the post is labelled with (can be one or more)

- Title - main title of the post

- Body - main content of the post

- Trackback - links back from other sites

- Comments - comments added by readers

- Permalink - the URL of the full, individual article

- Footer - usually at the bottom of the post, often showing post date/time, author, category, and stats such as number of reads, comments or trackbacks.

Studies that focus on using blogs to improve writing skills show that blogs can be easily integrated into a virtual EFL writing environment (Hourigan \& Murray 2010). A lot of researches were led to examine how web-based tools could help develop the students' language ability. Aside from learning logs, chat rooms, online learning, weblogs are a kind of powerful teaching tool which were employed in many language teaching in recent years. It is very important to know some results of the previous studies about the effectiveness of using blogs in instruction to make sure of the benefits of using blogs in learning process. These researches assert the great and considerable effect of 
using blogs as a tool to enhance writing skills on EFL learners' writing performance, their ability to monitor writing, their attitudes towards and perceptions of writing, and their reactions and participation in writing projects (Kitchakarn, 2012\& Aydin, 2014).

Sun (2010) compared learners' writing performance to determine the effects of extensive writing on writing abilities. The study concluded that blogs enhance overall writing performance, promote autonomous writing, and result in positive attitudes towards EFL writing.

Aljumah (2012) examined students' perceptions and attitudes towards the utilization of blogs in teaching English written work course for EFL Majors at Qassim University in Saudi Arabia. He gathered data from 35 students through questionnaires. The findings demonstrated that students had a positive observation and disposition towards the use of blogs in their written work class. Outcomes likewise demonstrated that students felt advantages of using blogs to build inspiration and enthusiasm to use English.

Soares (2008) set up a class blog with her nine pre-intermediate EFL students in a language school in Brazil. She investigated the students' impression of the effectiveness of using blogs as a part of their English learning. She completed three-month exploratory practice. The results showed that the students find blogs as learning instrument for them and blogs helped in improving their English.

Noytim (2010) explored the high importance of using weblog in learning context of a university in Thailand. The study examined students' perceptions of and attitudes toward using weblogs. There were twenty undergraduate English major students who were getting ready to become English teachers at a secondary level. They attempted coursework and showing practicum in secondary schools. 


\section{Context of the problem:}

Teachers face many obstacles in English language teaching, for instance, inadequately equipped classrooms and educational technology. They lack opportunity to use English in their daily lives. Moreover, most students hate to write as they have no experience, no confidence and maybe no ideas about what they write about. Therefore, students should practice, practice and still more practice to learn writing. They are always hesitant to write because they cannot generate ideas and they are afraid of making mistakes (Abdel-Hack, 2009b).

To document the problem, a pilot study has carried out by the researcher on (31) third year students (English major) at Benha faculty of Education during the first term of the academic year 2017/2018. The results of the test revealed that there is that there is a notable shortage in their writing structure and unity skills.

\section{Statement of the problem}

There is a lack in EFL writing structure and unity skills among third year students- Faculty of Education- Benha University. So, there is a need to use anew tool such as edublog to improve these skills.

\section{Questions of the Study}

To face this problem, the present study attempted to answer the following questions;

1- What are the EFL writing structure and unity skills required for prospective teachers in Benha University Faculty of Education?

2- What are the features of using edublogs for prospective teachers in Benha University Faculty of Education in improving writing structure and unity skills?

3- What is the effectiveness of using edublogs in improving EFL writing structure and unity skills among prospective teachers in Benha University Faculty of Education? 


\section{Delimitations of the Study}

This study is delimited to the following:

1- A sample of third year students in Faculty of Education- Benha University.

2- Some sub skills of writing structure and unity required for third year students in Faculty of Education- Benha University.

\section{Procedures of the Study}

The following procedures will be followed to carry out the present study:

1- Identifying the EFL writing structure and unity skills and sub skills required for EFL students in the Faculty of Education;

- Reviewing literature and previous studies related to EFL writing structure and unity skills

- Preparing a list of EFL writing structure and unity skills and sub skills required for EFL students in the faculty of Education.

- Submitting the list to a jury member to verify its validity.

- Modifying the list according to the jury members' point of view.

2- Identifying to what extent students in the Faculty of Education master the writing structure and unity skills;

- Designing the EFL writing structure and unity pre- test to assess the student's EFL narrative writing skills.

- Submitting the test to a jury to modify them.

- Modifying the test according to the jury's opinion.

- Selecting a sample of EFL third year students in Faculty of Education Benha University.

- Applying the pre-test to only one group of EFL third year students for identifying what writing structure and unity skills they have. 
3- Identifying the features of edublog through:

- Reviewing the literature and previous studies related to the edublogs.

- Identifying and applying the procedures to the group of the study that will be followed during using the blog.

- Applying the post-test to the group of the study for identifying to what extent they master EFL writing structure and unity skills.

4- Collecting and statistical analysis of the data.

5- Analyzing and interpreting results.

6- Recommendation and suggestions.

\section{Participants}

The participants of the present study consisted of EFL prospective teachers (third year English Section) at Faculty of Education, Benha University during the academic year 2017/2018. The final number of the students was (31) students who attended almost all the sessions of the treatment and the pre- and post-applications of the instruments of the study.

\section{Instruments of the study}

1- An EFL writing structure and unity Skills Checklist.

2- An EFL Pre writing structure and unity test to measure students' writing structure and unity skills.

3- An EFL Post writing structure and unity test to measure students' writing structure and unity skills.

4- An EFL writing structure and unity skills rubric to score students' performance on the EFL writing structure and unity skills tests.

\section{Validity of EFL writing structure and unity skills tests:}

In order to validate the EFL writing structure and unity tests. Tests were submitted to some of the jury members in curricula and methods of Teaching English .They were asked to indicate the suitability of the test content for the academic level of the study sample (third Year English 
Language Department Students at Benha Faculty of Education and the clarity of the instructions for each part of the test. They indicated the suitability of the tests and how far each question of the tests assesses the skills intended to measure. Most of the jury members also indicated the suitability of the tests to its main objectives and the consistency of questions to the tests' objectives. According to the jury's' opinions and suggestions, the modifications would be performed to the tests' content to get its final form.

\section{Reliability of the pre-test}

The reliability of the test was measured using the test-retest method:

\section{a) Test-retest method}

The test was administered to a group of $3^{\text {rd }}$ year English section students at the Faculty of Education, Benha University (other than the experimental group who received the treatment by the edublog) $(\mathrm{N}=25)$ during the first semester of the academic year 2017/2018. Then, it was administered to the same group again after two weeks. The Pearson correlation between the two administrations was (.996) which is significant at the 0.01 level. This means that the EFL writing structure and unity pre-test is reliable.

\section{b) Inter-rater method}

Inter-rater reliability means two or more raters/observers give consistent estimate of the same test and this method is used to avoid the subjectivity factors in grading. Accordingly, the researcher gave an English language instructor ${ }^{(*)}$ a copy of students' answers to the EFL writing structure and unity pre-test and the rubric to estimate the students' answers.

(*) Ghada Elsadek ESP English language Instructor at Benha University 
Comparing the results of the two raters, it was found that the Pearson correlation was (.970) which is significant at the 0.01 level.

\section{Reliability of the post-test}

The reliability of the test was measured using the inter-rater method:

\section{Inter-rater method:}

Inter-rater reliability means two or more raters/observer give consistent estimate of the same test and this method is used to avoid the subjectivity factors in grading. Accordingly, the researcher gave an English language instructor a copy of students' answers (video) to the EFL writing structure and unity post-test and the rubric to estimate the students' answers. Comparing the results of the two raters, it was found that the Pearson correlation was (.978) which is significant at the 0.01 level.

\section{Aim of the Study}

The study aimed at enhancing some of the EFL writing structure and unity skills for third year students, enrolled in English section at Benha Faculty of Education.The researcher uses edublogs to accomplish the study aims, so by the end of the treatment students will be able to Identify the importance of EFL writing structure and unity skills to English language learners.

\section{The Experimental Treatment}

The present study focused on developing the study participants' writing structure and unity skills, through the use of some technological materials, traditional and online activities. The treatment was "writing a well-structured and unity text". The treatment lasted for three sessions in two weeks. The students were guided by the researcher during using the edublog. The students were guided by the researcher during using the edublog. The participants started to use edublog. They uploaded videos and pictures that explain how to make their writing structured and develop their 
writing unity as well. In groups, they started to write essays. They were asked to make sure that their texts are well structured. They had to use words to connect the ideas inside each paragraph and inside the essays as a whole. They had to present events in proper sequence and correct timeorder, use the basic components of the narrative writing: the orientation, the complication and the resolution and the re-orientation and use strong verbs that can carry and convey more meaning than a string of weak words. In addition, the study participants were asked to use precise or accurate nouns that can deliver a word picture and to comment on their colleagues' writing and suggest adding or removing certain words. Consequently, the study participants' writing structure and unity skills were developed greatly in the post-assessment of the EFL writing structure and unity test than the pre assessment of the post-test due to the effect of edublogs.

These results are consistent with previous research that proved the effect of the using weblogs on improving grammatical skills. For example, Zhang (2009) found out in his study, blogging "affects the writing unity and structure," (p. 67) since students have their audience in mind while writing. Therefore, edublog may be considered as an effective platform in facilitating the development of students' structure and unity skills.

\section{Evaluation techniques}

Two evaluation techniques were used by the researcher; formative assessment and summative assessment.

\section{1- Formative assessment}

Formative assessment was used for assessing the participants' progress in EFL writing structure and unity skills and for providing necessary and immediate positive feedback. The activities quizzes provided the researcher with the sufficient information about the participants' progress and development in EFL writing structure and unity skills. 


\section{2- Summative assessment}

Summative assessment was conducted at the end of the treatment through the application of the EFL writing structure and unity post-test to measure the achievement of the using edublogs.

Table (1): Results of "t" test between the pre and the post-test mean scores of the participants of the present study in Unity

\begin{tabular}{||c|c|c|c|c|c|c|c||}
\hline \hline Skills & Application & $\mathbf{N}$ & Mean & S.D & T-value & D.F & Sig. \\
\hline \hline \multirow{3}{*}{ Unity } & Pre- & 31 & 1.0000 & .00000 & & & \\
\cline { 2 - 6 } & Post- & 31 & 4.5806 & .62044 & & \multirow{3}{*}{32.132} & \multirow{2}{*}{0.01} \\
\hline
\end{tabular}

Table (1) illustrates that the mean scores of the participants of the present study in the post-assessment of unity skills are higher than those of the pre-assessment scores, where $t$-value is (32.132)

Results of the present study confirmed that there is a statistically significant difference between the mean scores of the participants of the present study in the pre- post assessment of EFL writing unity skills in favor of post assessment".

Table (2): Results of " $t$ " test between the pre and the post-test mean scores of the participants of the present study in structure skills

\begin{tabular}{||c|c|c|c|c|c|c|c||}
\hline \hline Skills & Application & $\mathbf{N}$ & Mean & S.D & T-value & D.F & Sig. \\
\hline \hline \multirow{3}{*}{ Structure } & Pre- & 31 & $\mathbf{3 . 1 9 3 5}$ &. $\mathbf{4 0 1 6 1}$ & \multirow{2}{*}{66.971} & \multirow{3}{*}{30} & \multirow{2}{*}{0.01} \\
\cline { 2 - 7 } & Post- & 31 & $\mathbf{1 3 . 8 0 6 5}$ & $\mathbf{. 8 3 3 4 4}$ & & & \\
\hline
\end{tabular}

Table (2) illustrates that the mean scores of the participants of the present study in the post-assessment of structure skills are higher than those of the pre-assessment scores, where t-value is (66.971).

Results of the present study confirmed that there is a statistically significant difference between the mean scores of the participants of the present study in the pre- post assessment of EFL writing structure skills in favor of post assessment". 


\section{Reference}

Abdallah, M.M. (2015).Writing II for 2nd year EFL student teachers. Doctoral Dissertation. University of Exeter, England, UK.

Abdel-Hack, E. M. (2009b). Task-based learning as an off shoot of communicative language teaching: implications in writing production. In, A.A. El-Marasafy and E.M. Abdel-Hack (Eds), New Trends in Teaching Reading and Writing, (pp.211-270). Benha, Egypt: Middle East Center for Educational Services.

Abu Bakar, N., Latif, H. \& Ya'acob, A. (2010). ESL Students feedback on the use of blogs for language learning. 3LThe Southeast Asian J. Eng. Lang. Stud.16 (1), 120-141.

Akdal, D. \& Şahin, A. (2014). The effects of intertextual reading approach on the development of creative writing skills, Eurasian Journal of Educational Research, 54, 171-186.

Ali, H.S.B., (2016). The Effectiveness of Using the Corpus Approach in Developing Writing Skills and Reducing Writing Anxiety among EFL Student Teachers.(Doctoral Dissertation), faculty of Education, Benha Univesrsity.

Aljumah, F.H. (2012). Saudi Learner perceptions and attitudes towards the use of blogs in teaching English writing course for EFL majors at Qassim University. English Language Teaching,5(1),100-116.

Aydin, A. (2014). The Use of Blogs in Learning English as a Foreign Language. Mevlana International Journal of Education (MIJE). vol. 4(1), pp. 244-259

Boas, I. V., (2011). Process Writing and the Internet: Blogs and Ning Networks in the Classroom. English Teaching Forum, 2. (26-33).

Carolan, F., \& Kyppö, A. (2015). Teaching process writing in an online environment. In J. Jalkanen, E. Jokinen, \& P. Taalas (Eds), Voices of pedagogical development - Expanding, enhancing and exploring higher education language learning (pp. 13-30). Dublin: Research-publishing.net. 
Curran, K. \& Marshall, D. (2011), Blogs in education. Advanced Engineering Informatics. Vol, 36. P. 3515-3518

Dewi, W. R.,(2013). Weblogs; an Alternative Solution in Improving High School Students' Writing Skill. Online Submission.

Dirgeyasa, I. W. (2014). Genre-Based Approach: What and How to Teach and to Learn Writing. National Council of Teachers of English 9, (9).

Duffy, P. \& Bruns, A. (2006).The Use of Blogs, Wikis and RSS in Education: A Conversation of Possibilities. In Proceedings Online Learning and Teaching Conference 2006, pages pp. 31-38, Brisbane.

Elashri, I.I. (2013). The Effect of the Genre-Based Approach to Teaching Writing on the EFL Al-Azhar Secondary Students' Writing Skills and their Attitudes Towards Writing. doctoral dissertation, Faculty of Education, Mansoura University.

Framework. Australasian Journal of Educational Technology. Vol. 26(2), 209-225

Graham, S., \& Harris, K. R. (2005).Improving the Writing Performance of Young Struggling Writers Theoretical and Programmatic Research from the Center on Accelerating Student Learning. The journal of special education,39(1), 19-33.

Hourigan, T., \& Murray, L. (2010). Using blogs to help language students to develop reflective learning strategies: Towards a pedagogical

Hussin, S., Abdullah, M. Y. Ismail, N. \& Yoke, S. K. (2015). The Effects of CMC Applications on ESL Writing Anxiety among Postgraduate Students. English Language Teaching, 8(9).

Isleem, H. A. (2012). A suggested Program Based on Individualized Activities for Developing Palestinian Sixth Graders' Writing Skills. Master Thesis. Faculty of Education. The Islamic University- Gaza. 
Karadeniz, A. (2017). Cohesion and Coherence in Written Texts of Students of Faculty of Education. Journal of Education and Training Studies, Vol. 5, No. 2, P. 93-99

Kitchakarn, O., (2012). Using Blogs to Improve Students' Summary Writing Abilities. Turkish Online Journal of Distance Education,13 (4), Article 13 .(209-219).

Noytim,U. (2010). Weblogs enhancing EFL students' English language learning. Procedia Social and Behavioral Sciences, 2, 1127-1132.

Raimes \& Miller-Cochran (2013). Keys for writing. USA. Wadsworth, Cengage Learning

Raimes, A (2002). Ten Steps in Planning a Writing Course and Training Teachers of Writing. In J. C. Richards \& W. A. Renandya (Eds.), Methodology in language teaching (pp. 306-314). An Anthology of Current Practice. Cambridge: Cambridge University Press,

Ray, J. (2006). Welcome to the Blogoshere: The educational use of blogs. Kappa Delta Pi Record, 42(4), 175-177.

Richardson, W., (2010). Blogs, wikis, podcasts, and other powerful web tools for classrooms. Thousand Oaks, CA: Corwin Press. Third edition

Ryan, M. (2014). Writers as Performers: Developing reflexive and creative writing identities. English Teaching: Practice and Critique,13(3) pp. 130-148.

Sadik, A. (2009). Cognitive and metacognitive writing strategies and their relations to writing performance of EFL learners (Doctoral Dissertation). Makassar, Indonesia: UniversitasHasanuddin.

Sahin, M.\& Genc, B. (2015). Writing Self-Efficacy of International Students Learning Turkish as a Second Language. The Reading Matrix: An International Online Journal, 15(2). P. 210- 217 
Salem, A.A. (2013). The Effect of Using Writer's Workshop Approach on Developing Basic Writing Skills (Mechanics of Writing) of Prospective Teachers of English in Egypt. English Language Teaching,6 (7).

Seow, A. (2002). The writing process and process writing. In J. C.

Soares, D. (2008). Understanding class blogs as a tool for language development. Language Teaching Research 12,4 (2008); pp. 517533

Sun, Y. C. (2010). Extensive writing in foreign language classrooms: A blogging approach. Innovations in Education and Teaching International, 47(3), 327-339.

Tangpermpoon, T. (2008). Integrated Approaches to Improve Students Writing Skills for English Major Students. ABAC Journal ,28(2).

Toci, A. (2014). Evaluating ESL Students' Creativity in Writing. Journal of Foreign Language Teaching and Applied Linguistics. DOI10.14706, 31-39

Torkildsen, J.V., Morken, F., Helland, W. A. \& Helland, T. (2015).The dynamics of narrative writing in primary grade children: writing process factors predict story quality. Read Writ. Published online: 31 December 2015.

Witte, S.P. \& Faigley, L. (2003). Cross-Talk in Comp Theory: Coherence, Cohesion, and Writing Quality Ed. Victor Villanueva Washington State University.

Zhang, D. (2009). The Application of Blog in English Writing. Journal of Cambridge Studies, Vol 4. No. 1. Pp 64-72 